\title{
КАЗАКИ-НЕКРАСОВЦЫ ОСМАНСКОЙ ИМПЕРИИ В ОПИСАНИИ М. С. ЧАЙКОВСКОГО (МОХАММЕДА САДЫК ПАШИ)
}

\author{
A. А. Пригарин
}

Пригарін О. А. Козаки-некрасівці Османської імперії в описанні М.С. Чайковского (Мохаммеда Садик Паші). У статті розглядається сюжет існування та діяльності козаків-старовірів (некрасівців) у складі Османської імперії у середині ХІХ ст. Показується як глобальні схеми історії можуть не співпадати 3 минулим локальних спільнот. Наводиться переклад фрагменту оригінального джерела - опису М.С. Чайковського (1857 р.).

Ключові слова: козаки-некрасівці; старообрядці; Османська імперія; М.С. Чайковський.

Пригарин A. А. Казаки-некрасовцы Османской империи в описании М.С. Чайковского (Мохаммеда Садык Паши). В статье рассматривается сюжет существования и деятельности казаков-староверов (некрасовцев) в составе Османской империи в середине XIX в. Показано, как глобальные схемы могут не совпадать с прошлым отдельных локальных общностей. Приводится перевод фрагмента оригинального источника - описания М.С. Чайковского (1857 г.).

Ключевые слова: казаки-некрасовцы; старообрядцы; Османская империя; М.С. Чайковский.

Prigarin A. A. The Cossacks-nekrasovtsy of Ottoman Empire in M. S. Tchaikovsky's (Mohamed Sadyk Pasha) Description. In the article the plot of existence and activity of Cossacks-Old-believers (nekrasovtsy) in composition of the Ottoman Empire in the middle of $19^{\text {th }}$ century is examined. It is shown how global charts of history can't coincide with the past of separate local communities. The translation of the fragment of original source, descriptions of M. S. Tchaikovsky (1857) is given.

Keywords: Cossacks-nekrasovtsy; old believers; Ottoman Empire; M. S. Tchaikovsky.

История казаков-некрасовцев, покинувших Дон и Россию в начале XVIII века и создавших эффективные способы выживания и выразительные варианты казацкой традиции в составе Османской империи, полна «белых пятен». Несмотря на наличие в историографии фундаментальных работ по прошлому этой самобытной группы казачества ${ }^{1}$, многие из вопросов их жизнедеятельности в составе мусульманской державы остаются открытыми. Особо подчеркнем актуальное значение бытования небольшой организованной общины «древлего православия» в исламском государстве. При этом, как правило, и верно служа Высокой Порте, эти христиане выступали весомой силой во внутренних и внешних событиях Османского государства, в частности, участвуя на стороне Турции в войнах против России (все военные кампании XVIII - первой половины XIX вв.). Ряд сюжетов легендарного прошлого этой группы казаков не вписывался ни в одну из версий официальной истории, оставаясь в стороне от имперских дискурсов воюющих сторон.

В силу такого парадокса справедливо был поставлен вопрос о выявлении и накоплении новых источников, непосредственно отображающих положение внутри данного социума и событийные аспекты развития некрасовских казаков ${ }^{2}$. Обнаруженный нами текст является одним из самых ранних описаний группы. Познавательный характер публикуемой ныне работы обусловлен тем фактом, что ее автор был знаком с корпусом материалов, недоступных современному исследователю, а также опирался на собственные наблюдения и диалоги с самими некрасовцами. Это позволяет оценивать данный труд в двойном значении: и как историографический факт, и как источник с широким эвристическим диапазоном. Многие из сюжетов выступили впоследствии планом-содержанием для создания различных линий в исследовании некрасовской группы. Например, автор был первым, кто зафиксировал и описал т.н. «Заветы Некрасова», которые и по сей день являются важным концептом в понимании феномена русских казаков на «службе турецкой».

Весьма яркой и оригинальной личностью следует считать и самого автора источника - Михала Станиславовича Чайковского (Мехмеда Садык Пашу, Чайку; 1804-1886). Его биография и эволюция взглядов привлекали ${ }^{3}$ и, уверен - еще будут привлекать внимание специалистов ряда дисциплин. Связано это, по-видимому, с тем, что он никак “не хотел” вписываться в обычные категории государственных, революционных или нацио-

(C) Пригарин, А. А., 2015 
налистических схем. Разноплановая деятельность этой фигуры - выразительный пример космополитизма: служа делу польской революции, пропагандировал идеи “независимой Украины”, преданно выполнял военные и административные функции в империи Порты, последовательно доставляя разведанные в пользу Франции сведения... Каждой из этих линий вполне хватило бы на самобытную биографию; объединение их всех в судьбе одного человека сложно объяснимо с позиций бытового мышления и оценок.

Кульминацией карьеры этой неординарной личности следует считать создание и функционирование «Османского казачьего войска» (в 1853-1868 гг.) ${ }^{4}$. Он создал его на свой страх и риск, легализовав в обстоятельствах Крымской войны. В состав этого войска вошли украинские и русские жители Северо-Западного Причерноморья, польские эмигранты в Стамбуле. Планировалось присоединение и другого славянского населения империи в число Войска. Сам М.С. Чайковский видел его цель в “воссоздании казацкой народности в Южной Руси, или, как минимум, образовании из Добруджы самостоятельного казацкого государства под моим руководством как султанского вассала"5. Деятельность созданного М.С. Чайковским воинского подразделения, еще ожидает своего исследователя. Нас же интересует литературный аспект деятельности Садык Паши. На пике своей активности он создал сборник «Казачина в Турции» (“Kozaczyna w Turcyi”), который вышел ограниченным тиражом в 1857 году в Парижеб. Результаты его творчества следует расценивать как нечто среднее между беллетристикой (с художественным вымыслом, метафорами и другими атрибутами подобного жанра) и пропагандой. Поэтому вряд ли стоит искать достоверности в изложении М.С. Чайковским прошлого - оно для него обладало не столько источниковой ценностью для познания, сколько выступало в качестве предмета вдохновения и сокровищницы фактов, которые можно было использовать для популяризации собственных идей. В связи с этим его наследие следует рассматривать как своеобразную модель мировоззрения, искавшей в историческом опыте обоснования для выстраивания новых форм идеологии. Поэтому не станем искать в его текстах соответствия реальной истории, а выясним семиотические (знаковые) сюжеты и события, на которые опирался автор в своем желании обосновать правомерность собственных действий. Благодаря такому подходу становится возможным продемонстрировать эволюцию взглядов автора: от романтика к прагматике практика. В результате, будем иметь дело с проявлениями социальной памяти, со всеми свойственными данному типу сознания мифотворческими аспектами, к которому вряд ли эффективно применять научно-строгий корпоративный “костюм” требований.

Выходя из понимания труда как эклектичного по своим функциям, сфокусируемся на описании некрасовских казаков, которое оставил М.С. Чайковский. Этот фрагмент является одним из первых в литературе комплексной характеристикой казаков-староверов на османской службе. По ходу размышлений заметим, что это произведение неоправдано “забыто" в историографии - даже в специально посвященной ему литературе чаще всего используются мемуарные оправдания “Записки”, составленные на два десятилетия позже в Киеве, уже после возвращения в Российскую империю. Анализируемый сборник подготовлен вне цензурных рамок, в непосредственной близости от событий, в момент искренней веры в будущее своего детища. Книга является компиляцией фольклора, документов, описаний собственных наблюдений, которые написаны польско-украинско-русской языковой смесью. Вышла она небольшим тиражом и уже при жизни автора стало библиографическим раритетом, чем частично и объясняется редкость ее использования в историографии. В приложении к данной публикации приводится фрагмент сборника (7-й раздел из 28) в собственном переводе. Это четвертый параграф первой части сборника. Публикуется под авторским заглавием. Заглавные буквы и абзацы оставлены вслед за М.С. Чайковским.

В немногочисленных отзывах на книгу М. Чайковского с конца XIX века доминирует критика Ф.К. Волкова: “невыразительные и отрывочные сведения этого писателя... настолько запутаны и тенденциозно обработаны, что не могут иметь никакого значения без самой тщательной проверки каждого из приведенных им фактов"8. Безусловно, с точки зрения документальной позитивистской парадигмы (правил критики источников) произведение “атамана" ангажировано, чрезмерно эгоцентрично и содержит множество фактографических недостатков. Однако вряд ли стоит его оценивать исключительно с позиций 
профессионального историка - его задачи были, конечно же, иными, нежели у кабинетного ученого, что следует учитывать при работе с текстом этого произведения.

Фрагмент сборника публикуется с максимально точным сохранением стиля и грамматического строя М.С. Чайковского. Ключевые названия приведены в квадратных скобках согласно оригиналу. Таким же образом приведены комментарии. Многие из фактографических аспектов, безусловно, нуждаются в последующей источниковедческой критике. Неточности характеризуют как собственные познания М.С. Чайковского (например, постоянное упоминание дат восьмой русско-турецкой войны как «1827-1828» вместо 18281829 гг.), так и историческую память самих некрасовцев (яркий случай - связь переселения из России не во времена Петра I, что имело место в реальности, а в период Екатерины I). Большинство из описанных сюжетов в последующем «перекочевали» в историографию, что также требует специального внимания.

\section{Приложение}

\section{IV $V^{9}$ Несколько слов о Казаках Некрасовиах. Писано в Лагере над Камчиком}

[Salmanie nad Kamczykiem] 6 Сентября 1856 года

Казаки Некрасовы поселены здесь в Азии в Санджаке Брусси [Brussy] в уезде Бандерма [Banderma], в селе Бинэвле [Binewle], насчитывая тысячу домов над озером Майнос [Mainos], и поэтому его зовут Майноским селом -как его прозвали Игната Некрасова Казацкое Войско, Кубанские Казаки и Михайлицы [Ihnata Nekrasy Kozackie Wojsko, Kubancy Kozacy I Michailiczcy]. Последнее название происходит от места Михайлица над морем Мраморным, двадцать часов дороги от Бинэвле. Поселение Некрасовцев отдалено на четыре мили пути от Бандермы, а на пять - от Эрдека, двух мест над морем Мраморным, а от Брусси шестнадцать часов - час турецкий пять верст московских.

Казаки эти происходят из Дона - во время Екатерины I, императрицы Московской, вышли из Отчизны под предводительством Стеньки Разина, по причине преследований религиозных [фактическая ошибка: после восстания 1707-1709 гг. часть казаков покинула российские пределы и обосновались на Кубани. - А. П.]. После второго сражения в Уральских землях, над Волгой, с Московскими войсками, пришли служить войском у Ханов Татарских - были они тогда под предводительством Наместника Разина Игната Бурьяна [Ihnata Burjana], которого Москали прозвали Некраса (неудачный) [Nekras (niepiekny)], по причине их присяги на службу военную у Мусульманского Хана первого Христианами.

По приказу Гетмана Некрасы достигли города Анапы, а затем округи Кубани аж до устья Лабы, отданной его казакам, и с тех пор взяли название Кубанские Казаки - СтароКубанцы [Kubanscy Kozacy-Staro-Kubancy].

Между теми Казацкими выходцами, были первые семьи Донские: Булгаковы, Евсеевы, Мазаны, Хохлы, Грицкие, Солтаны и т.д., но эта аристократия первая Донцев, заселенная Польской шляхтой прибывшей на Дон из Карабоя [Karabojem], более привязана была к Старообрядческому согласию. Женщины и семьи стали после приходить к отцам, мужьям и братьям. Анапа заселилась этими Казаками, местность поделили на станицы, как на земле Донской и с теми же самыми названиями.

Игнат Некраса обязал этих мужчин нести службу войсковую Ханам, двенадцать тысяч пятьсот конных Казаков, поделенных на двадцать пять Полков, и охранял пешими и на лодках место от нападения неприятеля.

Игнат Некраса учредил в организации военной, гражданской и религиозной сотоварищество выходцев, которое с этого времени носит название: Войско Игната Некрасы Казаков [Wojsko Ihnata Nekrasy Kozakow]. Организация, права и уставы какие он дал, до настоящего дня действуют как самые святые, как самые актуальные в Бинэвле.

Игнат Некраса был пожилого возраста, но в девяносто верхом погиб под Анапой, охраняя этот город, когда его штурмовали Москали, под предводительством Фельд-Маршала Гудовича. Долгое время честь его гремела, и он и не думал о выборе нового Атамана: он бы заслуженным и самовластным - в тех выходцах нужна была такая сила, чтобы удерживать порядки, убеждения и заслуги, в лице своего Начальника.

После смерти Игната Некрасы Анапа была взята, но Казаки из нее вышли, жены, дети и старики на лодках, а мужчины и молодцы на конях. Вдоль самых берегов плыл флот се- 
мей казацких, а побережьем шли походом конные Казаки - и так пришли аж до Босфора. Переправили этих коней из Анадол Каваки до Румелии Каваки. И снова берегами аж на Дунай, где они поселились над озером Разин, очень рыбном и имеющим выходы в Черное море при Кара Кермане [Kara Kermanie] и в Дунайское Георгиевское русло [Dunajskie Giorgiewskie koryto].

Как у Ханов, так и у Султанов Исламского Царства, приняли службу воинскую. В их первом фирмане, вернее договоре [Paktach Konwentach], содержались такие выражения:

«За гостеприимство для живых, для приют для умерших на Твоей земле, великий и могучий Монарше, клянемся Тебе кровью отплатить охраной твоего святого Трона и твоей Великой Державы. Своими средствами обязуемся на каждой войне против Москвы, на своих конях со своим оружием, а взамен от Твоего Султанского Монаршества нам, есть дома и скалы, собирать дополнительно средства на подковы, по две пары на коня, живность для людей и коней, золото во время войны, как даешь ты твоим Шахам» [Уникальный фрагмент текста договора - М.С. Чайковский, видимо, имел возможность познакомиться с оригиналом, этот источник нигде не упоминается в работах по истории Некрасовского войска. - А. П.].

Вольными были они от всяческих налогов и выплат - свободно рыбу и пиявок ловили и тем торговали, а во время войны конными выходили на службу. Обычно власть военную имел над ними Сераскир-Паша [Seraskier-Pasza], так же как над Запорожцами имел Капудан Паша [Kapudan Pasza]. По мере заселения давали должное количество ездоков и к этому их обязали, но точное число их определял приказ Сераскира: какие сведения дали и дополняли убыль в часы войны. Осели над Дунаем, верные и старательные в Султанской службе, аж до прихода Запорожцев на правый берег Дуная. Тогда затеяли споры и свары между ними.

Некрасовцы выселились над берегом моря Мраморного, а над рекой Марица осели в близости ее устья около Эноса над озером Сыралджа [Syraldga], часть их перешла в Азию на озеро Майнос.

В войне 1827 [так в тексте, но имеется в виду российско-турецкая война1828-1829 гг. - А. П.] года Некрасовцы приняли активное участие, но когда их конница вышла под Шумлу [Шумен], под командованием Великого Визиря Мехмед Решид Паши [Wielkiego Wezyra Mehmed Reszyd Paszy], полк Московских уланов под командованием полковника Муханова, вышла к селам казацким над Сыралджи - некоторое время они там пребывали, ничего особенного не сделали, но по окончанию войны Некрасовцы эти перешли в Азию на озеро Майнос.

Чума сначала, а затем холера опустошила эти села; в 1854 их всех было не более ста казаков. Служили все на войне под командованием Мехмеда Садык Паши; после войны распущены по домам, согласно их договоренностям с Турцией.

Казаки Некрасовские во время своей службы в Турции получили от Султанов Мустафы [Mustafa], Абдул-Хамида [Abdul-Hamid], Селима [Selim] и Махмуда [Mahmud] двадцать восемь Фирманов с благодарностью за их верность и с похвалой их храбрости. От Султана Махмуда имеют Фирман с благодарностью за оборону Стамбула в 1828 году, имеют в знак награды три булавы: серебренная от Султана Селима, вторая - такая же - от Султана Абдула-Хамида, а третья - золотая от Султана Махмуда.

В году 1856 вместе с первым полком Казаков Оттоманских Некрасовские Казаки, находясь на службе, получили медали славы за участие в войне и четыре медали пятого класса на сотню. Великую ценность и признание придают они этим Фирманам и этим наградам, которые сложены в Арсенале, вместе со знаменами и с тремя пушками, вывезенными еще из Анапы.

Имеют они булаву серебренную самого Игната Некрасы и палицу, которой, говорят, он был проткнут, и оковы, в которых приговаривал заковывать виновников. Эти всяческие реликвии, как и булава Есаульская, которые носят Атаман войска и Есаулы в случае получения ими власти.

Имеют свою большую хоругвь, на лазурном фоне профиль золотой креста греческого, а в углу хоругви Архангел Михаил золотой. Такие же точно хоругви имеют и двенадцать меньших с крестами греческими и полумесяцами Османскими и звездами, которые со времен уничтожения Янычар и Шахов, отобраны у башибузуков. Эти хоругви и древние бунчуки и хоругви забраны от Москалей и бунчуки от Черкесов, которых было тридцать, 
сейчас находятся в кладовой. Там же Архив войсковой, регистр Казаков, описи каждой компании, заверенные подписями и печатями Старшины.

Книги церковные и другие военные, которые постановили хранить как память войсковую, находятся в Сокровищнице [Skarbiec] и Арсенале. В нем имеется множество разного оружия различного времени. Это все располагается в двух церквях. В третьей - Архив и Канцелярия, а в четвертой пребывает это богатство в воскресенье, и в дни малых праздников, и в большие Праздники, это все достается. И тогда можно увидеть и Арсенал, и Сокровищницу.

Главной основой этого решительного общества является вольность труда и пожитков, а не получение сильной власти земной.

Игнат Некраса в Заветах [Ustawach] повелевал: «Пожитки имейте с чего есть; больше рыбы ловите, торгуйте, но помните о порядке наказания от Атамана и Старшины; оплачивайте работу каждого, согласно заработанному, прибыль честью должна быть разделена на три части: первая Церкви, вторая - резерв войска, а третья тому, кто этот доход торговый получил» [это самый ранний из записанных вариантов «Заветов Некрасова»; лишь через десяток лет более полный вариант был описан В.И. Кельсиевым ${ }^{10}$. -А. П.].

Во всей округе Бинэвле не имеют ни огородов, ни полей вспаханных, ни виноградников. Хаты как на выгоне и все поля окружены лесом. Вся земля принадлежит посторонним - грекам и туркам; казаки получают ее и обрабатывают, пропалывая виноградники и огороды. Каждый имеет оружие, еду и вино, но собственности существенной не имеет.

В Стамбуле у Власти получают они право на лов рыбы и пиявок в озерах. Около Стамбула, Смирны, Бургаса, Варны, в Добрудже, около Солоник, Самсона, Бруссы, одним словом по всей Румелии и Анатолии - соль, рыба, икра, клей выступают главной основой их торгового богатства.

В День Святого Дмитрия [Dzien Swietego Dymitra] собирают круг Старшины под руководством Атамана Войска и перед ними стоят предприниматели-наниматели и рыболовы. Если предприниматели имеют свои средства, то определяют им озера на наем, если же нет, то одалживают из кассы войска и указывают процент, положенный с этого, лодки и, как говорят они, целый завод рыбацкий.

В это время Атаман со Старшиной назначают каждому заводу Атамана Ватажка (Начальника), казначея, писаря и казаков на рыбную ловлю, разделяющих общее звание артели. Каждая из этих артелей имеет своего десятника, то есть чауша [czausza]. Все казаки от восемнадцати аж до пятидесяти лет обязаны работать по приказу Атаманского войска. До достижения ими восемнадцати, а также после пятидесяти, зависело от их воли и от рекомендаций их прочими мужчинами в адрес Атамана Войска.

Так устроено разделение, что своими Ватажками управляются они на рыболовстве. Предприниматели участвуют в распределении, но Ватажек командует, писарь записывает улов каждого. Ватажка назначают люди до сдачи свежей рыбы. Что старшина предпринимателю передает, соль и рыба иные продукты, писарь записывает, а казначей складывает деньги в кассу.

Рыболовство начинается в конце Октября, а прекращается в конце Апреля, потом начинается ловля пиявок [т.е. сразу после дня Св. Димитрия (26 октября по церковному стилю); конец рыбной ловли связан был, видимо, с днем Св. Георгия (24 апреля). Такое разделение на зимний и летний циклы календаря одновременно отображают и древнеславянские представления и соответствуют балканско-анатолийской традиции, в основе которой находился лунные овцеводческие даты. - А. П.].

На Святого Михаила [Swiety Michal - 7 (21) ноября] все кассы вращаются в Бинэвле, Атаман со Старшиной подводят итог, выплачивают рыбакам и изымают положенную прибыль, делят между рыбаками. Ватажков, как и всех урядников, устанавливают на следующий год старшины и Атамана. Во время работы наказания и поучения как во время службы в войске, такие же уважения старшинству и такие же порядки.

Когда они вели другую торговлю, например, благородным товаром, кожей или чем иным, то вели ее таким же способом.

На протяжении двух веков пока общество войсковое находится на турецких землях, ничего не слышно было о спорах расчетных, о жалобах, которые выходили бы за пределы 
войска Игната Некрасы Казаков или, чтобы они искали справедливости у властей высших Османского государства, или властей меньших. Не только является это добровольному следованию обычаев, но и чувство высокой чести патриотичной.

Нельзя вступать Некрасовцам в связи брачные, только с женщинами своего рода и своего вероисповедания. В свою военную общину непримиримую берут только Донцев, которые доказывают свое чистое происхождение из Дона и согласия староверского. И детей другого происхождения принимали, приспосабливая к своим, воспитывая их в своей вере, обычаях и повинностях.

Монахов звали не иначе как Иноками, передавая сие учение детям. И нет Некрасовца, чтобы не умел читать, писать, считать, не знал хорошо своего исповедания и истории своего войска.

Так глубоко подозревали Москву и Греков, что не имели у себя попов своей веры даже - опасаясь их, чтобы они не были агентами и шпионами Москвы. При крещении детей, при венчании, когда таких наберется несколько, приглашали самого лучшего попа Греческого исповедания из-за границы войска. Хорошо платили, но требовали, чтобы не проговорился - приезжавший в село, в сопровождении стражи из двух Казаков с обнаженными палашами, которые им всегда товарищи - так же привозил и так отвозил в его усадьбу. Если вынуждены ему были дать есть и пить, то потом все вещи выкидывали - так же делали в отношении любого Грека или Армянина, которых ненавидели [конфессиональный обычай «держать посуду», распространенный среди старообрядцев в отношении внешнего мира, получил особый смысл этнического и религиозного знака в условиях инокультурного проживания. - А. П.].

Эти Некрасовцы фанатично привязаны ко всяческим обрядам староверского исповедания, но духовенства не любят и у себя не имеют, как Староверы из Добруджи. В теологию веры не входят, удовлетворяясь поверхностно - троекратно осеняя крестом перед всякой едой и питьем уста и входя в избу, где образа. Не пили цветы [чай; herbaty] из-за того, что Екатерина Королева России велела его пить и пьют его Москали; не пили кофе и не курят табак, так как Мусульмане, Католики, Православные, Израильтяне и иные признают кофепитие и курение. Перед началом работы, перед тем как сказать что-то, то они непременно троекратно крестятся крестом святым. В церкви придерживаются этого же, бьют поклоны, поют псалмы, но, не имея ни музыки, ни науки религиозной.

Это все есть доказательством того, что в глубине они не являются фанатиками своего согласия, только вскользь следуют поверхностным знаниям постов и обрядов, как границы для удержания войска в таком положении, в каком его оставил Игнат Некраса. Не из-за религиозности, но из-за патриотизма.

Суды всяческие устраивают перед своим кругом Старшины, под председательством Атамана войска, за три проступка наказание смертью назначается.

За ложь в слове любом делают наперво клятву религиозную. Преступника наказывают, привязав камень к шее и сбрасывая в озеро.

За предательство войска, бегство во время боя. Наказание смертью от пули или палаша.

За умыкания чужой жены или девицы Некрасовской, на которой потом не женился виновника наказывают наглядно, лупя его на плацу публично и розгами, пропуская его через весь строй войска, пока смерть ему не наступала. Если виновник добровольно признавал вину, тогда такое же наказание следовало.

У Некрасовцев в Бинэвле разводов не имелось, у Староверцев иных достоинств бывало, как и у Греков.

К каре приговаривали Атаман и круг Старшины - только убийство совершалось самими Казаками по принципу кровь за кровь. Если случайно, семья убитого может забрать убийцу, если не простила, может пожелать кровь за кровь.

В году 1855 Игорь Грицык поручик Михайловской сотни, по дороге из Сливны в Варну был убит случайно одним из своих товарищей, даже родственника своего. Следствие нашло доказательства с помощью Сотника и Старшины, убедилось, что убийство произошло случайно. Паша приказал отпустить арестованного, но жена Грыцыка начала кричать и требовать кровь за кровь. И пять мужчин признали, что преступник должен быть наказанным за иные провинности, и вскорости совершили суд по тому наказанию. Трудно, но следствие властей высших смогло только установить, что это была кровная месть. 
Так глубоко была спрятана между Михайловскими Казаками тайна - можно было лишь догадываться об этом, и то только тем, кто знал обычай.

Не любили Некрасовцы, чтобы власть вообще вмешивалась в их дела, и потому стремились избегать споров со своими и прикрывать их у себя, сколько могли.

В году 1843 , Бей Турок, сосед Бинэвле, положил глаз на Некрасовку, работающую в поле - прибежала она в село, требуя справедливости и мести. Тихон Осипович Битиков, бывший тогда Атаманом Войска, сел на коня с сорока Казаками, прискакал к Бей Турку и в его собственном Чифлику расстреляли. Жена застреленного Бея поведала это Мадырю Бандермы [Mudyra bandermy]. Дело достигло Бруссы, назначено было следствие. Атаман, который приказал Казакам не ждать своего возвращения и приезда урядника, пришел к паше Бруссы и освидетельствовал: «Тот Бей поступил не как человек, а как свинья, и мы его как шкодливого зверя расстреляли. Все, как ты нам велел, всякий кто знает, может в этом заверить. Сами это признаем, пусть Султан делает с нами, что пожелает».

Паша начал торговаться, чтобы заплатили жене погибшего за кровь. Начал говорить: «Поможем даме коль бледна, раз просишь, но не за что платить, потому, как это означало бы признать вину, а мы ее не признаем, только справедливость исполнили». Паша не посмел их арестовать, отдал дело в Стамбул, и приговор не заставил ждать. Некрасовцам было запрещено, чтобы в иных случаях самостоятельно справедливости не вершили, только ждали ее от власти легальной.

Гостеприимство у них большое, хлебосольство, как его зовут, является результатом следования Заветам Некрасы - любят беседовать, пьют очень даже много, но не так как Добруджанцы, как старые Запорожцы, как Поляки. Выпивают без шума, прилично, без авантюр. Перед тем как приступить к разговору Есаул заповедал, чтобы невольно никому Богоматери, сестры, жены, дочки ничьей или невесты не задевать. Если запретную тему затрагивали первый раз, то за воротник виновного выводил на двор Есаула и получал предназначенные пятьдесят палок Некрасы и возвращались к беседе. Кто затронул во второй раз, то выводили и били сто палок. Снова возвращались к беседе. В третий раз получал сто пятьдесят палок, его заковывали в оковы Некрасы и в течении пятнадцати дней он не имел права никуда ходить в гости.

Целый день пили, одной чашей по очереди, и ели разнообразные блюда из рыб, пироги и квашенные овощи. Битье палкой Некрасы и одевание кандалов Некрасы не считалось за унижение, более того, молодой Казак хвалился этим, что и он эти всяческие наказания отбыл и является настоящим Казаком. Является это неким испытанием на рыцарство. Что в доме, что в обозе, что на работах, любят очень общаться между собой. Не любят сами не есть, не пить. На беседах рассказываются старшими часами песни народные молодым, но криков, визгу и ссор не бывает нигде.

Урядники выбирались такие: Атаман Войска, Есаул, Тержуман [Terdzuman - Тарджуман (арабский) или Драгоман, т.е. толкователь, переводчик. - А. П.], десятники. Урядниками являлись и Старики, двенадцать из которых составляли совет. Исполнительная власть была в руках Атамана, который имел себе помощника Есаула. В руках Стариков есть власть законная и никто не может записаться в войско без их Совета с Атаманом, по достижению ими если не единогласного, то решения голосованием.

Урядники эти выбирались на один год, но часто - права подтверждали на следующий год, даже получали на дольше, потому как Некрасовцы не любят перемен. Выборы проходят согласно обычаю, но не в их характере, ни в их душе.

На службу военную поступают согласно высшему Указу Султанскому, который оговаривал какое количество Казаков должно быть. Как только приходил Указ в село, Атаман его оглашает, и в течение дней десяти все Казаки от пятнадцати до пятидесяти лет собрались на майдане главном, где уже заседала Старшина с Атаманом. Каждый подходил к ним, сняв шапку, осенял себя крестным знамением три раза и бросал шапку за себя. Когда все прошли, тогда Старики вставали и перемешивали шапки всех Казаков. После перемешивания выбирали нужное количество, какое приказано предоставить Казаков, каждый узнавал свою шапку и считался зачисленным.

Атаман со Стариками выбирали Сотника, которого звали Атаманом Походным; двух поручиков, которых звали Полковниками; Знаменщика, бравшего Хоругвь; двух Бунчужных, бравших малые хоругви; Есаула и Терджумана, который должен был уметь [понимать. - А. П.] по-турецки. Был еще Писарь войсковой и добавляли двух Стариков, 
следивших за властью моральной, что-то наподобие Цензоров Римских или Комиссаров Республики Французской над властью военной. Их никто заменить не мог, они могли смениться только по требованию офицеров, по желанию круга и новым выбором. Такой новый выбор бывал только формой плена, потому что никто не смел сделать ничего другого - только то, что они велели и говорили. Десятников выбирал Атаман Походный, если есть больше сотни, то он носил это имя, если нет, то просто сотника, в первом случае в каждой сотне имелись сотник и офицеры без звания. А штаб главный состоит из Атамана Походного, Терджумана и Есаула; Есаул сотни получает название Чауша.

Из кассы главной, каждому Казаку для коня либо на коня, на вооружение, обмундирование и ежегодный заработок выдавали, чтобы оставили семьям на содержание, и назначают день сбора вооруженными и на конях.

В этот день Старики и Атаман Войска снова садятся на майдане, выезжали один за другим по кругу офицеры и прочие казаки. Каждый кланялся, трижды крестился и молвил: «Старики, если кто-либо из вас, чтобы позаботился о грешной душе моей и взял ее под опеку?». Молчание три раза, пока кто-то из Стариков позовет его по имени такойто и такой-то, «едь с Богом». Казак преисполненный бодростью, что его не оставят на войне, так как является обязанным перед старшим достойного и выслуженного у Бога и в войске.

Если молчание это не прерывалось, ощущения печальные, ибо без опеки и никакой определенности в смерти. И в дивном таком случае редко когда Казак возвращался обратно домой с войны. В году 1854 Казаки показали четырех молодых людей необязанных, которые выехали из Бинэвле в большой печали непризнанности из-за того, что ранее пили в корчме и были наказаны властью Атамана Войска. Один из них пропал под Силистрой, другой под Тульей, а двух взяли в плен там же.

После этого смотра стреляют из пушек, выносят из Церкви Хоругви и две меньшие, когда едет одна сотня. Знаменнщик и Бунчужные присягают, что никогда ее не отдадут неприятелю, а все Казаки - что их не уничтожат. Такие это святыни духовные, что до сих пор еще Некрасовцами ни одного знамени войскового не утратили. Как большое признание ценности хоругви приведем следующий случай:

В году 1810 Москали хотели захватить мост в Мачине. Атаман Черноморских Казаков Черник [Ataman Czarnomorskich Kozakow Czernik] с войсками подошел к берегу, опередив Турков и Запорожцев, которые его охраняли. Тогда ему с этой целью пришлось штурмовать более тысячу всадников Некрасовских под руководством Атамана походного Хохла. Хохол не мог вернуть убегавших, а также не мог конницей удержать Черноморцев. Попал один, а потом второй и третий бунчуки в руки Москалей, приказал «все желающие - на кони и за знаменами!». Срочно кинулись люди, но он видел, что их мало - взял большую хоругвь в руку и приказал «кто Старо-Кубанец - по коням за мной за знаменами!». Двинулись эти, конницей ударили, половину Черноморцев посекли, половина бежала. Хохол собственноручно убил Черника.

Старики постарше застали невредимыми мундир и знаки офицерские Черника в семье Хохола. Сын Хохла растратил все, что осталось от отца, а два его внука жолнеры в сотни в 1854, 55 и 56 годах рассказывали, что этот мундир был взят им как награда за отбор и охрану знамен.

При получении Хоругви, знамен, Полковники выстраивают сотни, сотники стоят перед ними, Атаман Походный командует и те выдвигаются в поход под песни.

Очень верой своей привязаны они к забобонам и чарам: Иван Солтан, Атаман Походный, в войне 1827 и 28 имел огромное влияние на этих казаков и через эту веру. Они были убеждены в достоинстве и отваге этого воина, потому как ему было видение, что он не будет убит ни оловом, ни железом. В каждой битве был всегда впереди, а, возвращаясь, перевязывал раны. Он снимал свой пояс, и пули с него ссыпались на землю - Казаки считали, что это были неприятельские, которые застревали в поясе. Для них был это человек, которого они боялись и уважали и которому доверяли.

С малых лет Некрасовцы старшие обучают детей службе, стрелять, скакать, атаковать и обороняться, и к этой службе военной они необычно подходят и обречены - в каком бы то ни было мужчине, без капли умения это сидит в крови и проявляется, когда это потребуется.

Ни один неприятель не сумеет подойти к их домам, такая бдительность, такая осторожность, такое молчание в пикетах, быстрота в оседлании коней, и в одежде аккуратнос- 
ти, и в собрании пунктуальность. На их учтивость и внимательность можно оставить любой транспорт, понимая ценность экспедиции, быстро и в целости его доставят. В дороге не запачкаются, не испоганятся, повинность и служба у них - прежде всего.

В бой идут так же, как и казаки Донцы, не прячась, один Начальник едет впереди, остальные позади от начальника, не сильно отступая.

Их служба войску Турецкому всегда была преданной и в последней войне не одна добрая услуга ими предоставлена. Несколько сотен казаков в этом смысле и с такой старательностью военной, для командования легкой конницы, по удержанию передовых охран и коммуникаций, и даже полиции войсковой, в составе войска. Это большая сила, которая малочисленна, но которая конницу заменить может. Так быстро по заданию передвигаясь для Командира, что он может быть спокоен о своей экспедиции, о транспорте, о фураже и о полиции. А, кроме этого, есть уверенность, что стража будет бдительной, а приказы исполнены быстро.

Некрасовцы, нигде прежде в откомандирование не отправили одного человека, всегда трех или не меньше двух - на случай слабости и чтобы каждый был перед глазами, под контролем другого. И это предусмотрено их Заветами военными еще Игната Некрасы.

Имея, равно как и Донцы, склонность к разбою и к трофеям военным, но умеют это делать тихо, без визга и шума, так что редко на них жаловались - свои поборы получали как легальность, и нигде между ними не было гвалта, драки и обидных угроз. Жестокости без необходимости нигде они не допускают.

В 1827 году Иван Солтан допустил подобную жестокость в отношении пленных Московских, обрезал им уши, продырявил их по краям и отослал Царю Николаю. Пояснял это так через переводчиков: «Мы и Донцы являемся одной кровью, одной костью, они служат белому Царю и их много и много. Мы служим Султану и есть нас мало - в порядке вещей так есть, что всегда многое поглотить малое может. От Начальства зависит, чтобы этого не было - мои своих братьев могли бы отдать в неволю, что понятно, и тогда мы бы были уничтожены. А так они видят, как я обхожусь с Московскими пленными, каждый себе думает «хоть бы эта и месть была, но где бы он такое получил от Москаля» и «не дает себя в плен брать. Где нельзя силой, там необходимо ненавистью и умением воевать».

Этот Иван Солтан был человеком крайне приверженным обычаям, воздержанным, несовременным и в интересах своего войска глубоким политиком.

В Турции, и у Правительства, и среди Люда Некрасовцы были в большом уважении и авторитетными. У Люда есть пословица: «Верный как Игнат Казак - на его веру полагаться как на веру Старо-Кубанцов». Нет солдат в турецком войске, нет Паши наивысшего звания, который сердцем и разумом не приветствовал Некрасовца и который бы ему выразил негодование.

Является это сложной, но заслуженной наградой. Потому как общество выходцев, которые на чужой земле, и через два века сумело сохранить в себе народность, честь, уникальность и умения. Которое и через два века протягивали руки мужественности, отдавая должное заслугам предков, не прося ничего у разных людей и политиков. Лишь кровь и труд отношение к ним определяет. И привило мечты у правнуков такие же, какие были у их праотцов, которые не смогли сохранить земли отчизны перед натиском и не смогли вынести общего ярма, покинули его для того, чтобы сберечь народность, веру и честь. Общество это все сохранило, и, может быть, самое важное для людей - сердца и душу, которые только ждут призыва от Великого человека своего, хоть из Майноского села, хоть с берегов Казачьего Дона.

В конце несколько слов их народной песни, которая не является одной из самых поэтичных, однако ее все поют на марше хором. Точно так же ее пели Донцы всяческих станиц. В пении и хоре эта песня очень быстрая, азартная и развеселая. И Некрасовцы ее досконально знают - поют и другие, но они похоже на Украинские или на Московские, а не обладают таких черт народности Казацко-Донской как эта:

Из Царьграда, града,

Идут Гайдамаки,

Эй! Вэй! Вэй! Вэй!

Шлам бам бам, шлам бам бам,

Шлам бам, бам бам бам, 
Идут Гайдамаки,

Игнашки Казаки;

Эй! Вэй! Вэй! Вэй!

Шлам бам бам и т.д.

Идут на лодках,

Bсе красивы шапки

Эй! Вэй! Вэй! Вэй!

Шлам бам бам и т.д.

Прийдут до Болгару,

К Соленому яру

Эй! Вэй! Вэй! Вэй!

Шлам бам бам и т.д.

Солонину жарят,

И курицу варят.

Эй! Вэй! Вэй! Вэй!

Шлам бам бам и т.д.

Приехали к жиду,

В сам шабаш на беду,

Эй! Вэй! Вэй! Вэй!

Шлам бам бам и т.д.

Требуют горилки,

Четыре бутылки.

Эй! Вэй! Вэй! Вэй!

Шлам бам бам и т.д.

Вдарил жидок драпака,

Жидовочка казачка,

Эй! Вэй! Вэй! Вэй!

Шлам бам бам и т.д.

Жидовочка казачка

За рученки взяла,

Эй! Вэй! Вэй! Вэй!

Шлам бам бам и т.д.

В зеленый сад завела,

На кроватку легла,

Эй! Вэй! Вэй! Вэй!

Шлам бам бам и т.д.

На кроватку легла,

Рученки поднесла.

Эй! Вэй! Вэй! Вэй!

Шлам бам бам, шлам бам бам,

Шлам бам, бам бам бам.

Казаки Михайлицы носят красные шапки сделанные четырехгранно как конфедератки, золотая нить вдоль края, с черной окантовкой по кругу. Жупан песочный, верх черный из шерсти и шаровары синие. Казаки в темно-гранатовых жилетках без рукавов.

Старшинские знаки на шапке, в кокардах и перьях серебренные. Все внешне как соколы выглядят, все как прирожденные Господа. Все дельные ездоки на конях, как бы к ним приросли, как старинные центурии. Через горы и долины, через леса и степи, моря и пустыни летели б птицами! Ради того, чтобы на земле Разинов и Игнатов, на земле своих праотцев запеть:

Шлам бам бам, шлам бам бам,

Шлам бам, бам бам бам.

Это их мечта, это их идея. 
${ }^{1}$ Сень Д.В. «Войско Кубанское Игнатово Кавказское»: исторические пути казаков-некрасовцев (1708 г. - конец 1920-х гг.). - Краснодар: Кубанькино, 2002.

${ }^{2}$ Например: Dolgin V. Despre rolul documentelor otomane în istioria ruşilor de rit vechi din Romấnia / О роли турецких документов в истории русских старообрядцев Румынии / V. Dolgin, S. Fenogen // Зори-Zorile. - 2001. - № 10 (111). - P. 6-7.

${ }^{3}$ Rawita-Gawronski F. Kozaczyna za Dunajem // Atencum wileiskie. - R. IX. - 1933-1934. - S. 159198; Смоховска-Петрова В. Михаил Чайковский - Садък паша и българското Възраждане. - София, 1973. - 152 с.; Гросул В.Я. Российские революционеры в Юго-Восточной Европе. - Кишинев: Штиница, 1973. - С. 25-29; Борисёнок Ю. Атаман Садык-паша // Родина. - 1998. - № 5-6. - С. 94-97; Prigarin A., Sen D. Mihail Ceaikovski şi epoca sa // Magazin istoric. - Iunie 2009. - P. 53-57.

${ }^{4}$ Прігарін O.A. «Козацтво в Туреччині» М. Чайківського як джерело вивчення козацьких формувань в Оттоманської Порті середини XIX ст. // Наукові праці історичного факультету Запорізького державного університету. - Вип. ХІІІ. - Запоріжжя, 2001. - С. 17-28; Волконский М.А., Пригарин A.A., Сень Д.В. Панславизм Михала Чайковского и история казачества в Османской империи // Поляки в истории России: история и современность. - Краснодар: Кубан. гос. ун-т, 2007. - С. 147-160.

5 Чайковский М.(Садык-Паша). Записки // Киевская старина. - 1891. - Т. 33. - С. 108-109.

${ }^{6}$ Kozaczyna w Turcyi. - Paryz: w drukarni L. Martinet, 1857. - 391 p.

7 Чайковский М. (Садык-Паша). Записки // Киевская старина. - 1891. - № 1. - С. 40-72; 1891. № 2. - C. 255-268; 1891. - № 3. - C. 463-477; 1891. - № 4. - C. 117-130; 1891. - № 5. - C. 273-287; 1891. - № 6. - C. 446-457; 1891. - № 7. - C. 85-96; 1891. - № 8. - C. 195-211; 1891. - № 9. - C. 466477; 1891. - № 10. - С. 98-107; 1891. - № 11. - С. 276-291; 1891. - № 12. - С. 430-449.

${ }^{8}$ Кондратович $Ф$. Задунайская Сечь (по местным воспоминаниям и рассказам) // Киевская старина. - 1883. - № 1. - С. 29.

${ }^{9}$ Kozaczyna w Turcyi. - Paryz: w drukarni L. Martinet, 1857. - P. 79-100.

${ }^{10}$ Иванов-Желудков В. (В. Кельсиев). Русское село в Малой Азии // Русский вестник. - 1866. Т. 63. - Кн. 6. - С. 440-441; [Кельсиев В.И.] Очерк истории старообрядцев в Добрудже // Славянский сборник. $-1875 .-$ T. 1. - С. 605-620. 